\title{
MANAJEMEN LABA YANG DIPENGARUHI OLEH MANAGERIAL OVERCONFIDENCE DAN KEPEMILIKAN KELUARGA
}

\author{
Yuni Putri Yustisi'i); Destia Dwi Putri'²) \\ 1)Accounting Diploma Program, Universitas Teknologi Yogyakarta \\ 2) Sharia Accounting Study Program, STAIN Sultan Abdurrahman Kepulauan Riau
}

Email: 1)yuni.putri.yustisi@staff.uty.ac.id; ${ }^{2)}$ destia@stainkepri.ac.id

How to Cite :

Yustisi, et.al (2020). MANAJEMEN LABA YANG DIPENGARUHI OLEH MANAGERIAL OVERCONFIDENCE DAN KEPEMILIKAN KELUARGA. EKOMBIS REVIEW: Jurnal IImiah Ekonomi Dan Bisnis, 9(1). DOI: https://doi.org/10.37676/ekombis.v9i1.1271

\section{ARTICLE HISTORY \\ Received [30 Desember 2020] \\ Revised (24 January 2020] \\ Accepted [31 January 2021] \\ KEYWORDS \\ Managerial \\ Overconfidence, Earnings Management, Family Ownership}

This is an open access article under the $C C-B Y-S A$ license

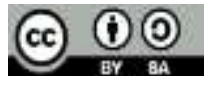

\section{ABSTRAK}

Penelitian ini bertujuan untuk mengetahui tindakan manajemen laba yang dipengaruhi oleh managerial overconfidence dan kepemilikan keluarga. Penelitian ini menggunakan sebuah indeks untuk dapat mengukur variabel managerial overconfidence yang dikonstruksikan pada komponen aktivitas investasi, aktivitas pendanaan, dan kebijakan dividen dengan median industri sebagai pembanding. Data yang digunakan adalah sampel perusahaan manufaktur yang terdaftar di Bursa Efek Indonesia selama tahun 2012-2017. Perusahaan manufaktur dipilih sebagai sampel penelitian dikarenakan perusahaan manufaktur memiliki tingkat volatility laba yang berubah-ubah. Metode penelitian yang digunakan dalam penelitian ini untuk menganalisis data dan menguji hipotesis adalah statistik deskriptif dan uji regresi linier berganda. Hasil pengujian statistik pada penelitian ini menunjukkan bahwa variabel managerial overconfidence berpengaruh positif terhadap manajemen laba. Selain itu, pengujian interaksi antara kepemilikan keluarga dengan managerial overconfidence tidak memperlemah terjadinya manajemen laba.

\section{ABSTRACT}

This study aims to determine that earnings management is influenced by managerial overconfidence and family ownership. This study uses an indeks to measure the managerial overconfidence variable which is constructed in the components of investment activity, financial 
activity, and dividend policy with the industry median as a comparison. The data used is a sample of manufacturing companies listed on the Indonesian Stock Exchange during 2012-2017. Manufacturing companies are selected as research samples because manufacturing companies have varying levels of earnings volatility. This study's research method to analyze data and test hypotheses is descriptive statistics and multiple linear regression. The results of statistical tests in this study indicate that the managerial overconfidence variable has a positive effect on earnings management. In addition, testing the interaction between family ownership with managerial overconfidence does not equate to improved earnings management.

\section{PENDAHULUAN}

Sistem pelaporan keuangan bertujuan untuk memberikan informasi yang relevan kepada investor, kreditor, dan semua pemangku kepentingan untuk membantu mengevaluasi kinerja manajemen (Yuan dan Jiang, 2008). Akan tetapi, terdapat beberapa skandal pelaporan keuangan (seperti manajemen laba) dapat menyebabkan turunnya kepercayaan investor terhadap kapabilitas tata kelola perusahaan. Beberapa perusahaan dapat melakukan praktik manajemen laba untuk memberikan gambaran mengenai kondisi perusahaan agar pemangku kepentingan akan menilai kinerjanya dapat memenuhi target perusahaan (Fields, Lys, dan Vincent, 2001). Manajemen laba dianggap tidak etis karena niat manajemen dapat menyesatkan beberapa pemangku kepentingan dan dianggap mempengaruhi kredibilitas perusahaan, pasar modal, dan dapat menyebabkan informasi laba menjadi bias dalam memperkirakan arus kas masa depan (Healy danWahlen, 1999; Hashim dan Devi, 2007).

Perilaku overconfidence (terlalu percaya diri) terdapat pada faktor psikologis dan karakteristik pribadi pada manajerial yang mengarah pada perilaku oportunistik. Teori keagenan, asimetri informasi, dan hipotesis arus kas bebas tidak dapat sepenuhnya menjelaskan perilaku manajemen yang tidak rasional (Lin, $\mathrm{Hu}$, dan Chen, 2005). Manajerial yang terlalu percaya diri cenderung mengumumkan perkiraan laba yang bias ke atas dan dapat memberikan salah saji laba yang tidak disengaja atau disengaja. Hal tersebut menunjukkan bahwa managerial overconfidence mengarah pada ekspektasi kinerja masa depan yang tinggi, dimana manajer mungkin lebih cenderung mencari peluang untuk melakukan manajemen laba (Hribar dan Yang, 2016; Schrand dan Zechman, 2012; Li dan Hung, 2013).

Managerial overconfidence mungkin saja terjadi pada perusahaan dengan kontrol keluarga. Pada perusahaan keluarga, kekayaan keluarga berhubungan erat dengan nilai perusahaan dan memperhatikan prospek bisnis jangka panjang, sehingga cenderung melupakan keuntungan jangka pendek yang berasal dari manajemen laba (Anderson dan Reeb, 2003; Miller, Breton-Miller, dan Scholnick, 2008). Pihak internal pada perusahaan keluarga memiliki kekuatan untuk mengendalikan kegiatan perusahaan terkait investasi dan keputusan operasi (Ali, Chen, dan Radhakrishnan, 2007; Srinidhi, He, dan Firth, 2014). Beberapa penelitian menjelaskan bahwa informasi keuangan seperti pelaporan laba pada perusahaan keluarga cenderung memiliki 
kualitas laba yang rendah dan terdapat potensi melakukan manajemen laba yang tinggi (Fung, Su, dan Gul, 2013; Jaggi, Leung, dan Gul, 2009).

Penelitian yang pernah dilakukan oleh Lin dan Hung (2013) menjelaskan bahwa managerial overconfidence (manajerial yang terlalu percaya diri) meningkatkan perilaku manajemen laba pada perusahaan di Taiwan. Selain itu, perusahaan dengan kontrol keluarga cenderung akan memperlemah hubungan positif antara managerial overconfidence dan manajemen laba. Beberapa penelitian menunjukkan bahwa perilaku CEO keluarga berbeda dengan CEO non keluarga karena persaingan dari pasar tenaga kerja, rencana kompensasi, tekanan yang berkaitan dengan kinerja perusahaan, dan karakteristik bisnis keluarga (Anderson dan Reeb, 2003).

Penelitian ini juga melengkapi penelitian yang dilakukan oleh Schrand dan Zechman (2012) yang menjelaskan bahwa manajerial yang terlalu percaya diri merupakan sumber bias optimis dari kesalahan pelaporan keuangan perusahaan dan cenderung melakukan kesalahan dalam menilai keputusan investasi dan pembiayaan, tidak menjelaskan secara spesifik mengenai bentuk kesalahan pelaporan keuangan, seperti adanya indikasi melakukan manajemen laba. Manajemen laba bisa terjadi pada lingkungan perusahaan yang memiliki manajerial dengan sifat yang terlalu percaya diri karena manajerial tersebut memiliki dorongan untuk melaporkan laba yang tinggi.

\section{LANDASAN TEORI}

\section{Teori keagenan}

Teori keagenan didasari adanya perilaku pihak-pihak yang terlibat dalam perusahaan yaitu pemilik dan manajemen (Wolk, Dodd, dan Rozycki, 2013). Teori ini menunjukkan adanya hubungan antara prinsipal (pemilik) dan agen (manajemen perusahaan). Hubungan tersebut dapat menyebabkan adanya konflik kepentingan antara pihak yang terlibat, karena pemilik dan pengelola perusahaan memiliki tujuan yang berbeda. Perbedaan tujuan dan kepentingan tersebut dapat menimbulkan asimetri informasi (Jensen dan Meckling, 1976).

Konflik kepentingan yang terjadi di perusahaan apabila dihubungkan dengan teori keagenan memiliki dua tipe. Konflik keagenan tipe I lebih banyak terjadi pada perusahaan dengan kepemilikan tersebar. Sebaliknya, konflik keagenan tipe II lebih banyak terjadi pada perusahaan keluarga antara pemegang saham mayoritas dan pemegang saham minoritas. Para pemegang saham mayoritas yang memiliki hubungan keluarga dengan dewan direksi dan pihak manajemen akan lebih dipentingkan pemenuhan haknya dalam perusahaan (Atmaja, Haman, dan Tanewski, 2011; Srinidhi, He, dan Firth, 2014).

\section{Manajemen laba}

Manajemen laba terjadi ketika manajer menggunakan penilaiannya untuk mengubah laporan keuangan. Apabila terdapat manajemen laba yang luas, laporan keuangan mencerminkan kinerja perusahaan secara tidak akurat. Terdapat beberapa alasan manajer melakukan manajemen laba yaitu untuk memenuhi perkiraan analis keuangan, meningkatkan kompensasi yang akan diterima, dan mempengaruhi harga saham perusahaan (Healy dan Wahlen, 1999; Subramanyam, 2014).

Beberapa literatur akuntansi menunjukkan bahwa perusahaan dapat melakukan manajemen laba akrual atau manajemen laba riil. Manajemen laba akrual merupakan 
penyesuaian asumsi dan perkiraan dalam sistem akuntansi dan tidak mempengaruhi arus kas. Sebaliknya, manajemen laba riil merupakan praktik operasional normal perusahaan yang bertujuan untuk dapat menyesatkan setidaknya beberapa pemangku kepentingan sehingga mempercayai beberapa sasaran pelaporan keuangan tertentu (Roychowdhury, 2006).

\section{Managerial overconfidence}

Managerial overconfidence didefinisikan sebagai manajerial yang memiliki rasa percaya diri yang berlebihan. Manajerial yang terlalu percaya diri memiliki kecenderungan untuk melebih-lebihkan pengetahuan, kemampuan, dan ketepatan informasi yang diberikan. Perilaku tersebut dapat memberikan ilusi atau gambaran bahwa terdapat kemungkinan adanya salah saji yang tidak disengaja pada pelaporan keuangan perusahaan (Bhandari dan Deaves, 2006; Schrand dan Zechman, 2012).

Manajerial yang terlalu percaya diri akan cenderung meremehkan risiko keputusan, sehingga melebih-lebihkan nilai keputusan dan mengarah pada perilaku irasional tertentu untuk mencapai hasil yang dinginkan. Perilaku manajemen tesebut dapat mempengaruhi aktivitas akuntansi perusahaan yang berdampak pada laporan keuangan. Oleh karena itu, dapat disimpulkan bahwa manajerial yang terlalu percaya diri dapat terlibat dalam manajemen laba untuk keperluan informasi pribadi atau informasi kepada investor yang menyesatkan (Lin, Hu, dan Chen, 2005).

\section{Kepemilikan keluarga}

Kepemilikan keluarga yaitu perusahaan yang sebagian besar saham biasa dimiliki anggota keluarga yang terlibat secara aktif dan cenderung memiliki tata kelola perusahaan yang lebih rendah karena pengawasan dewan komisaris menjadi tidak efektif. Hal tersebut dapat berpotensi adanya asimetri informasi antara pemilik keluarga dan pemegang saham lainnya. Pemilik dalam perusahaan keluarga merupakan pemegang saham mayoritas dan akan lebih mengutamakan kepentingannya dibandingkan kepentingan pemegang saham minoritas (Wang, 2006).

Kepemilikan keluarga berdampak pada kualitas pelaporan keuangan melalui pengaruh entrenchment dan alignment. Pengaruh entrenchment dapat mendorong manajemen bertindak secara oportunistik dalam melakukan manajemen laba pada perusahaan keluarga. Sebaliknya, pengaruh alignment pada manajemen akan menyajikan kualitas laba yang tinggi, manajemen laba yang rendah, dan pengungkapan yang lebih luas (Nordin dan Hussin, 2009; Wang, 2006; Atmaja, Haman, dan Tanewski, 2011).

\section{Hipotesis \\ Pengaruh managerial overconfidence terhadap manajemen laba}

Manajerial yang terlalu percaya diri cenderung dikaitkan dengan bias optimis terhadap laba, manajemen laba riil yang lebih besar, dan kemungkinan lebih tinggi dalam melaporkan laba (Presley dan About, 2013; Chen, Ho, dan Ho, 2014; Hsieh, Bedard, dan Johnstone, 2014). Ketika perusahaan memperkirakan laba yang tinggi, tetapi tidak diikuti kinerja yang diharapkan, maka terdapat kemungkinan manajer melakukan manajemen laba yang lebih besar (Jaggi, Leung, dan Gul, 2009; (Schrand dan Zechman, 2012). Menurut La Porta et al. (1998), Indonesia dikategorikan negara dengan tingkat perlindungan investor yang rendah dan tidak memiliki mekanisme tata 
kelola eksternal yang efektif sehingga dapat membuat manajerial lebih mudah percaya diri untuk terlibat dalam perilaku manajemen laba. Jadi, hipotesis yang diajukan adalah: $\mathrm{H}_{1}$ : Managerial overconfidence berhubungan positif dengan manajemen laba.

\section{Pengaruh managerial overconfidence terhadap manajemen laba dengan dimoderasi kepemilikan keluarga}

Meskipun pihak manajemen terdiri dari anggota keluarga yang terlalu percaya diri, hal tersebut tidak akan meningkatkan motivasi untuk melakukan manajemen laba karena perilaku oportunistik akan merusak kinerja jangka panjang dan reputasi keluarga (Eddleston dan Kellermanns, 2007; Miller, Breton-Miller, dan Scholnick, 2008). Manajerial yang terlalu percaya diri dalam bisnis keluarga tidak perlu memanipulasi laba perusahaan dan mengambil keuntungan (Chu, 2011). Kepemilikan keluarga mampu menghindari tindakan oportunistik dengan menyajikan laba yang lebih informatif dan kualitas laba yang tinggi. Oleh karena itu, dapat disimpulkan bahwa kontrol kepemilikan keluarga dapat memoderasi pengaruh managerial overconfidence terhadap perilaku manajemen laba. Jadi, hipotesis yang diajukan adalah:

$\mathrm{H}_{2}$ : Kepemilikan keluarga memperlemah hubungan positif antara managerial overconfidence terhadap manajemen laba.

\section{METODE PENELITIAN}

\section{Data Penelitian}

Data yang digunakan merupakan data sekunder yang diperoleh dari laporan keuangan pada website resmi Bursa Efek Indonesia dan database BVD Osiris yang meliputi data perusahaan mengenai pengukuran manajemen laba, kepemilikan keluarga, dan data keuangan yang berkaitan dengan managerial overconfidence. Teknik pengambilan sampel dengan teknik purposive sampling dengan kriteria:

a. Perusahaan yang dipilih merupakan seluruh perusahaan manufaktur yang terdaftar di Bursa Efek Indonesia selama periode 2012-2017.

b. Perusahaan yang menerbitkan data keuangan, informasi tata kelola perusahaan yang disajikan secara lengkap, dan laporan keuangan yang telah diaudit.

c. Laporan keuangan berakhir pada tanggal 31 Desember.

\section{Variabel Penelitian}

a. Variabel dependen dalam penelitian ini adalah manajemen laba. Manajemen laba diukur dengan menggunakan dua komponen yaitu diskresioner akrual dan kualitas akrual dari Francis et al., (2005).

Komponen diskresioner akrual dihitung menggunakan nilai prediksi (predicted value) dari total current accruals (TCA) dengan persamaan sebagai berikut.

$\mathrm{TCA}_{\mathrm{i}, \mathrm{t}}=\alpha_{0}+\alpha_{1} \mathrm{CFO}_{\mathrm{i}, \mathrm{t}-1}+\alpha_{2} \mathrm{CFO}_{\mathrm{i}, \mathrm{t}}+\alpha_{3} \mathrm{CFO}_{\mathrm{i}, \mathrm{t}+1}+\alpha_{4} \mathrm{REV}_{\mathrm{i}, \mathrm{t}}+\alpha_{5} \mathrm{PPE}_{\mathrm{i}, \mathrm{t}}+\varepsilon_{\mathrm{i}, \mathrm{t}}$

Keterangan:

$\begin{array}{ll}\alpha_{0} & : \text { Konstanta. } \\ \alpha_{1-5} & : \text { Koefisien variabel independen. }\end{array}$

Journal Ekombis Review, Vol. 9 No. 1 January 2021 page: 121-134| 125 
TCA : total current accruals (laba bersih ditambah depresiasi dan amortisasi dikurangi arus kas operasi untuk perusahaan i pada tahun $t$ yang diskalakan dengan rata-rata total aset)

CFO : arus kas dari operasi yang diskalakan dengan rata-rata total aset.

$\triangle R E V \quad$ : perubahan pendapatan bersih untuk perusahaan i pada tahun $t$ yang diskalakan dengan rata-rata total aset.

PPE : property, plant, dan equipment untuk perusahaan i pada tahun t yang diskalakan dengan rata-rata total aset.

$\varepsilon$ : error.

Komponen kualitas akrual dihitung dengan menggunakan nilai residual dari persamaan accruals quality (AQ) yang merupakan hasil estimasi dari bagian innate atas akrual perusahaan. Persamaan $\mathrm{AQ}$ adalah sebagai berikut.

$\mathrm{AQ}_{\mathrm{i}, \mathrm{t}}=\alpha_{0}+\alpha_{1} \mathrm{SIZE}_{\mathrm{i}, \mathrm{t}}+\alpha_{2} \sigma\left(\mathrm{CFO}_{\mathrm{i}, \mathrm{t}}+\alpha_{3} \sigma\left(\mathrm{SALES}_{\mathrm{i}, \mathrm{t}}\right)+\alpha_{4} \mathrm{OPC}_{\mathrm{i}, \mathrm{t}}+\alpha_{5}\right.$ NEGEARN $_{\mathrm{i}, \mathrm{t}}$ $+\varepsilon_{i, t}$. (2)

Keterangan:

$\alpha_{0} \quad$ : Konstanta.

$\alpha_{1-5} \quad:$ Koefisien variabel independen.

$A Q \quad$ : accruals quality.

SIZE : : log dari total aset untuk perusahaan i pada tahun $\mathrm{t}$.

$\sigma$ CFO : standar deviasi arus kas operasi untuk perusahaan i pada tahun $\mathrm{t}$.

$\sigma$ SALES : standar deviasi penjualan untuk perusahaan i pada tahun t.

OPC : log siklus operasi perusahaan (360/(penjualan dibagi piutang lancar rata-rata) + 360/HPP dibagi persediaan rata-rata.

NEGEARN: laba negatif (rugi), diberi nilai 1 jika laba negatif, dan 0 jika laba positif. $\varepsilon \quad:$ error.

b. Variabel independen dalam penelitian ini adalah managerial overconfidence yang didefinisikan sebagai manajerial yang terlalu percaya diri sehingga cenderung menempatkan dirinya lebih tinggi dalam distribusi kemampuan ataupun kinerja dan diukur menggunakan lima indeks overconfidence dengan median industri sebagai pembanding. Apabila nilai perusahaan dari setiap indeks lebih besar dari median industrinya maka mengindikasikan bahwa overconfidence (Schrand dan Zechman, 2012). (1) IND_INDADJ (industry-adjusted excess investment) merupakan perhitungan pertumbuhan total aset terhadap pertumbuhan penjualan. (2) IND_NETADJ (industry-adjusted net dollars dari akuisisi yang dilakukan perusahaan). (3) DER_INDADJ (industry-adjusted debt to equity ratio) merupakan perhitungan dari total hutang terhadap total ekuitas perusahaan. (4) RISKYDT merupakan variabel indikator yang sama dengan satu jika perusahaan menggunakan obligasi konversi ataupun saham preferen, nol jika tidak. (5) DPR_INDADJ merupakan selisih dividend payout ratio dengan median dividend payout ratio industri.

c. Variabel pemoderasi dalam penelitian ini adalah kepemilikan keluarga. Kepemilikan keluarga diukur menggunakan persentase kepemilikan ekuitas yang dimiliki anggota keluarga, yaitu minimal memiliki $20 \%$ saham perusahaan (Anderson dan Reeb, 2003; Leung, Richardson, dan Jaggi, 2014; Wang, 2006).

d. Variabel kontrol dalam penelitian ini sesuai dengan beberapa variabel dari penelitian sebelumnya (Schrand dan Zechman, 2012; Li dan Hung, 2013):

1. SIZE, merupakan logaritma dari total aset perusahaan. 
2. LEV (leverage), merupakan rasio total utang dibagi total aset. Variabel kontrol ini dimasukkan karena perusahaan dengan leverage tinggi tidak dapat memperoleh keringanan dan dipaksa untuk merestrukturisasi hutang yang mungkin menghindari manajemen laba.

3. SALEGR (sales growth), merupakan total penjualan (current) dikurangi total penjualan (prior) dibagi total penjualan (prior).

4. BSIZE (board size), merupakan jumlah total anggota dewan komisaris perusahaan.

5. FCF (free cash flow), merupakan arus kas dari aktivitas operasi perusahaan dikurangi dengan net capital expenditure dan changes in working capital, kemudian dibagi dengan total aset (Ross, Westerfield, Jordan, 2010).

\section{Metode Analisis}

Teknik analisis data dalam penelitian ini yaitu analisis regresi linear berganda. Analisis data dalam penelitian ini terdiri dari statistik deskriptif, uji asumsi klasik, dan uji hipotesis. Data dianalisis menggunakan software SPSS versi terbaru dengan tingkat signifikansi $(\alpha)$ yang digunakan sebesar $5 \%$.

\section{HASIL DAN PEMBAHASAN}

\section{Statistik Deskriptif}

Statistik deskriptif bertujuan untuk mempermudah membaca dan memahami data yang digunakan dalam penelitian. Informasi yang disajikan merupakan data berupa total observasi, nilai maksimum, nilai minimum, nilai rata-rata, dan standar deviasidari masing-masing variabel. Hasil statistik deskriptif pada penelitian ini adalah sebagai berikut.

Tabel 1. Statistik Deskriptif

\begin{tabular}{|l|c|r|r|r|r|}
\hline $\begin{array}{c}\text { Variabel } \\
\text { Penelitian }\end{array}$ & $\begin{array}{c}\text { Tipe } \\
\text { Data }\end{array}$ & \multicolumn{1}{c|}{$\begin{array}{c}\text { Nilai } \\
\text { Minimum }\end{array}$} & \multicolumn{1}{c|}{$\begin{array}{c}\text { Nilai } \\
\text { Maksimum }\end{array}$} & $\begin{array}{c}\text { Nilai } \\
\text { Rata-rata }\end{array}$ & $\begin{array}{r}\text { Standar } \\
\text { Deviasi }\end{array}$ \\
\hline EMA & Rasio & $-0,12103$ & 0,12252 & 0,0002028 & 0,05020929 \\
\hline MO & Indeks & 0,00 & 0,80 & 0,2705 & 0,17992 \\
\hline FFAM & Dummy & 0,00 & 1,00 & 0,5661 & 0,49603 \\
\hline MO_FFAM & Interaksi & 0,00 & 0,80 & 0,1553 & 0,19510 \\
\hline SIZE & $\begin{array}{l}\text { Jutaan } \\
\text { Rupiah }\end{array}$ & 10.583 & 261.855 .000 & 8.358 .716 & 24.396 .930 \\
\hline LEV & Rasio & 0,00 & 5,06 & 0,5693 & 0,50297 \\
\hline SALEGR & Rasio & $-1,00$ & 35,83 & 0,2041 & 1,65054 \\
\hline BSIZE & $\begin{array}{l}\text { Jumlah } \\
\text { Dewan }\end{array}$ & 2,00 & 13,00 & 4,2068 & 1,75337 \\
\hline FCF & Rasio & $-0,52$ & 1,12 & 0,1235 & 0,15681 \\
\hline
\end{tabular}

Sumber data : Data Olahan dari SPSS

Berdasarkan hasil analisis deskriptif yang disajikan pada Tabel 1. diatas, dapat dijelaskan bahwa: 
1. Manajemen laba (EMA) terendah terjadi dengan nilai error $-0,12103$. Sebaliknya, nilai maksimum sebesar 0,12252 menunjukkan tingkat manajemen laba tertinggi. Nilai rata-rata manajemen laba sebesar 0,0002028 .

2. Variabel managerial overconfidence (MO) memiliki nilai minimum sebesar 0 dan nilai maksimum sebesar 0,80 . Nilai minimum 0 menunjukkan bahwa manajerial tidak memiliki perilaku overconfident. Nilai rata-rata managerial overconfidence sebesar 0,2705.

3. Variabel kepemilikan keluarga (FFAM) memiliki nilai minimum sebesar 0 dan nilai maksimum sebesar 1 . Nilai rata-rata kepemilikan keluarga sebesar 0,5661 menunjukkan bahwa $56 \%$ perusahaan sampel merupakan perusahaan keluarga.

4. Variabel ukuran perusahaan (SIZE) memiliki nilai minimum sebesar 10.583 juta rupiah dan nilai maksimum sebesar 261.855 .000 juta rupiah. Ukuran perusahaan memiliki nilai rata-rata sebesar 8.358 .716 juta rupiah.

5. Variabel leverage (LEV) memiliki nilai minimum sebesar 0,00 dan nilai maksimum sebesar 5,06. Rasio leverage yang tinggi menunjukkan bahwa perusahaan memiliki tingkat risiko yang tinggi karena memiliki kewajiban yang harus dipenuhi. Leverage memiliki nilai rata-rata sebesar 0,5693.

6. Variabel sales growth (SALEGR) memiliki nilai minimum sebesar $-1,00$ dan nilai maksimum sebesar 35,83 . Nilai minimum negatif menunjukkan bahwa terdapat penurunan penjualan. Sales growth memiliki nilai rata-rata sebesar 0,2041.

7. Variabel board size (BSIZE) memiliki nilai minimum board size sebesar 2 dan nilai maksimum sebesar 13. Board size memiliki nilai rata-rata sebesar 4,2068.

8. Variabel free cash flow (FCF) memiliki nilai minimum free cash flow sebesar $-0,52$ dan nilai maksimum sebesar 1,12. Free cash flow memiliki nilai rata-rata sebesar 0,1235 .

\section{Uji Normalitas}

Uji normalitas menggunakan uji statistik One-Sample Kolmogorov Smirnov. Residual dikatakan berdistribusi normal jika tingkat signifikansinya di atas 0,05 (nilai Sig. $>\alpha$ ). Sebaliknya, jika tingkat signifikansinya dibawah 0,05 (nilai Sig. $<\alpha$ ), maka residual tidak berdistribusi normal. Syarat terpenuhi apabila data berdistribusi normal (healy, 2018). Uji normalitas pada penelitian ini sebagai berikut.

\section{Tabel 2. Uji Normalitas}

\begin{tabular}{|c|c|c|r|c|}
\hline Model Penelitian & N & Kolmogorov-Smirnov Z & Sig. & Keterangan \\
\hline Pertama & 90 & 0,028 & 0,200 & Normal \\
\hline
\end{tabular}

Sumber data : Data Olahan dari SPSS

Berdasarkan tabel diatas menunjukkan bahwa model penelitian yang digunakan memiliki residual yang berdistribusi secara normal, yang dilihat dari nilai signifikansinya. Nilai Sig. pada model penelitian sebesar 0,200 > 0,05, maka dapat disimpulkan bahwa residual pada model penelitian berdistribusi normal. 


\section{Uji Multikolinearitas}

Uji multikolinearitas dilihat dari nilai VIF (Variance Inflation Factor) atau nilai tolerance. Model regresi yang baik seharusnya tidak terjadi korelasi diantara variabel independen. Regresi bebas dari multikolinearitas jika nilai Tolerance $>0,10$ atau nilai $\mathrm{VIF}<10$, artinya koefisien regresi tidak memiliki kesalahan sampling yang besar (tidak mengalami multikolinearitas) (Ghozali, 2018). Uji multikolinearitas pada penelitian ini adalah sebagai berikut.

Tabel 3. Uji Multikolinearitas

\begin{tabular}{|c|c|c|c|}
\hline $\begin{array}{c}\text { Variabel } \\
\text { Penelitian }\end{array}$ & $\begin{array}{c}\text { Nilai } \\
\text { Tolerance }\end{array}$ & Nilai VIF & Keterangan \\
\hline MO & 0,229 & 4,368 & Tidak terjadi multikolinearitas \\
\hline FFAM & 0,279 & 3,587 & Tidak terjadi multikolinearitas \\
\hline MO_FFAM & 0,177 & 5,635 & Tidak terjadi multikolinearitas \\
\hline SIZE & 0,531 & 1,882 & Tidak terjadi multikolinearitas \\
\hline LEV & 0,968 & 1,033 & Tidak terjadi multikolinearitas \\
\hline SALEGR & 0,993 & 1,007 & Tidak terjadi multikolinearitas \\
\hline BSIZE & 0,589 & 1,697 & Tidak terjadi multikolinearitas \\
\hline FCF & 0,935 & 1,069 & Tidak terjadi multikolinearitas \\
\hline
\end{tabular}

Sumber data : Data Olahan dari SPSS

Berdasarkan tabel diatas menunjukkan bahwa koefisien regresi model penelitian tidak terdapat korelasi di antara variabel independen. Hal ini dibuktikan dengan seluruh variabel penelitian seperti MO, FFAM, MO_FFAM, SIZE, LEV, SALEGR, BSIZE, dan FCF memiliki nilai Tolerance $>0,10$ dan nilai VIF $<10$.

\section{Uji Heteroskedastisitas}

Uji heteroskedastisitas diuji dengan menggunakan uji Gleijser. Model regresi yang baik adalah yang homoskedastisitas atau tidak terjadi heteroskedastisitas. Heteroskedastisitas terjadi, jika nilai Sig. $<\alpha$. Sebaliknya, jika nilai Sig. $>\alpha$, maka tidak terjadi heteroskedastisitas (Ghozali, 2018). Tingkat signifikansi yang digunakan untuk pengujian ini sebesar 5\%. Uji heteroskedastisitas pada penelitian ini adalah sebagai berikut.

Tabel 4. Uji Heteroskedastisitas

\begin{tabular}{|c|c|c|c|}
\hline $\begin{array}{c}\text { Variabel } \\
\text { Penelitian }\end{array}$ & Beta & Sig, & Keterangan \\
\hline MO & 0,016 & 0,097 & Tidak terjadi heteroskedastisitas \\
\hline FFAM & 0,005 & 0,110 & Tidak terjadi heteroskedastisitas \\
\hline MO_FFAM & 0,002 & 0,502 & Tidak terjadi heteroskedastisitas \\
\hline SIZE & $-0,010$ & 0,322 & Tidak terjadi heteroskedastisitas \\
\hline
\end{tabular}

Journal Ekombis Review, Vol. 9 No. 1 January 2021 page: 121-134| 129 


\begin{tabular}{|c|c|c|c|}
\hline LEV & $-0,009$ & 0,400 & Tidak terjadi heteroskedastisitas \\
\hline SALEGR & $-0,001$ & 0,214 & Tidak terjadi heteroskedastisitas \\
\hline BSIZE & 0,001 & 0,461 & Tidak terjadi heteroskedastisitas \\
\hline FCF & 0,000 & 0,514 & Tidak terjadi heteroskedastisitas \\
\hline
\end{tabular}

Sumber data : Data Olahan dari SPSS

Berdasarkan tabel diatas menunjukkan bahwa varian residual pada model penelitian ini dalam keadaan konstan (tidak mengalami heteroskedastisitas). Hal ini dibuktikan dengan seluruh variabel penelitian seperti MO, FFAM, AQ, MO_FFAM, MO_AQ, SIZE, LEV, SALEGR, BSIZE, dan FCF memiliki nilai Sig. > 0,05.

\section{Uji Autokorelasi}

Uji autokorelasi diuji dengan menggunakan uji Run Test. Pengujian Run Test digunakan untuk membuktikan bahwa data residual terjadi secara random atau tidak (sistematis). Autokorelasi terjadi, jika nilai Sig. $<\alpha$. Sebaliknya, jika nilai Sig. $>\alpha$, maka tidak terjadi autokorelasi (Ghozali, 2018). Tingkat signifikansi yang digunakan untuk pengujian ini sebesar 5\%. Uji autokorelasi pada penelitian ini adalah sebagai berikut.

Tabel 5. Uji Autokorelasi

\begin{tabular}{|c|c|c|c|c|}
\hline Model Penelitian & N & Test Value & Sig. & Keterangan \\
\hline Pertama & 90 & $-0,00045$ & 0,070 & Tidak terdapat autokorelasi \\
\hline
\end{tabular}

Sumber data : Data Olahan dari SPSS

Berdasarkan tabel diatas menunjukkan bahwa model penelitian yang digunakan tidak terjadi autokorelasi, yang dilihat dari nilai signifikansinya. Nilai Sig. pada model penelitian sebesar $0,070>0,05$, maka dapat disimpulkan bahwa data residual terjadi secara random atau tidak terjadi autokorelasi.

\section{Pengujian Hipotesis}

Pengujian hipotesis dilakukan untuk mengetahui pengaruh antar variabel independen, dependen, mediasi dan moderasi yang dapat diketahui dengan melihat nilai koefisien beta $(\beta)$ antar variabel dan tingkat probabilitasnya ( $p$ ) (Ghozali, 2018). Terdapat dua hipotesis yang diuji yaitu (1) menguji hubungan managerial overconfidence terhadap manajemen laba, (2) menguji hubungan managerial overconfidence terhadap manajemen laba yang dimoderasi oleh kepemilikan keluarga. Metode analisis yang digunakan adalah regresi berganda. Penelitian ini menggunakan tingkat signifikasi 5\%. Hipotesis terdukung apabila nilai Sig. $<a$ dan arah yang dihipotesiskan sesuai dengan koefisien Beta. Hasil pengujian hipotesis adalah sebagai berikut. 
Tabel 6. Pengujian Hipotesis

\begin{tabular}{|c|c|c|c|c|c|}
\hline $\begin{array}{c}\text { Variabel } \\
\text { Penelitian }\end{array}$ & $\begin{array}{c}\text { Prediksi } \\
\text { Arah }\end{array}$ & $\begin{array}{c}\text { Koefisien } \\
\text { Beta }\end{array}$ & $t$ & P-Value & Keterangan \\
\hline Constant & & $-0,007$ & $-0,474$ & 0,636 & \\
\hline MO & + & 0,032 & 2,008 & $0,045^{* * *}$ & Terdukung \\
\hline FFAM & & 0,002 & 0,407 & 0,684 & Main Effect \\
\hline MO_FFAM & - & $-0,002$ & $-0,101$ & 0,920 & Tidak terdukung \\
\hline SIZE & & 0,001 & 1,166 & 0,244 & Variabel Kontrol \\
\hline LEV & $-0,002$ & $-0,564$ & 0,573 & Variabel Kontrol \\
\hline SALEGR & 0,000 & $-0,404$ & 0,687 & Variabel Kontrol \\
\hline BSIZE & 0,002 & 2,443 & $0,015^{* * *}$ & Variabel Kontrol \\
\hline FCF & $-0,242$ & $-26,958$ & $0,000^{* * *}$ & Variabel Kontrol \\
\hline F & \multicolumn{7}{l}{} & $77,760(P \leq 0,000)$ \\
\hline Adjusted R Square
\end{tabular}

Sumber data : Data Olahan dari SPSS

Berdasarkan tabel diatas menunjukkan bahwa $\mathrm{MO}(\mathrm{H} 1)$ memiliki nilai Sig. sebesar 0,045 $<$ 0,05 dan arah yang diprediksikan sama dengan koefisien Beta dari hasil pengujian yaitu positif (+), maka dapat disimpulkan bahwa $\mathrm{H} 1$ terdukung. Variabel penelitian seperti MO_FFAM $(\mathrm{H} 2)$ secara langsung tidak berhubungan dengan EMA (hipotesis tidak terdukung), karena tidak memenuhi kriteria keterdukungan hipotesis.

\section{Pembahasan}

\section{Managerial overconfidence dengan manajemen laba}

Hipotesis pertama $(\mathrm{H} 1)$ pada penelitian ini menyatakan bahwa managerial overconfidence berhubungan positif dengan manajemen laba. Hasil pengujian pada hipotesis pertama menunjukkan bahwa managerial overconfidence berhubungan secara positif dengan manajemen laba $(\beta=0,032, p=0,045)$. Penelitian ini konsisten dengan penelitian Schrand dan Zechman (2012); Hillary dan Hsu (2011) yang menjelaskan bahwa manajerial yang terlalu percaya diri cenderung lebih tinggi dalam melaporkan laba dan melakukan manajemen laba yang lebih besar. Hasil penelitian ini juga melengkapi penelitian Li dan Hung (2013); Hribar dan Yang (2016); Libby dan Rennekamp (2012) yang menjelaskan bahwa manajerial yang terlalu percaya diri (overconfident) cenderung memiliki perilaku yang agresif atau tidak rasional sehingga akan melakukan perkiraan laba di masa depan dengan frekuensi yang lebih tinggi yang digunakan dalam keputusan perusahaan. Manajerial yang terlalu percaya diri dapat meningkatkan motivasi adanya manajemen laba dalam perusahaan dan dapat menyesatkan investor dengan menutupi perkiraan laba yang tidak masuk akal.

\section{Managerial Overconfidence, Kepemilikan keluarga, dengan Manajemen Laba}

Hipotesis kedua $(\mathrm{H} 2)$ pada penelitian ini menyatakan bahwa kepemilikan keluarga memperlemah hubungan positif antara managerial overconfidence terhadap manajemen laba. Berdasarkan hasil uji statisitik, hipotesis kedua tidak terdukung karena nilai signifikansinya melebihi $5 \%(p=0,920)$, artinya kepemilikan keluarga tidak mampu memperlemah hubungan positif managerial overconfidence dengan manajemen laba. Penelitian ini sejalan dengan temuan penelitian yang dilakukan oleh 
Abdullah dan Ismail (2016); Ball dan Shivakumar (2005) yang menjelaskan bahwa perusahaan dengan kepemilikan keluarga tidak memiliki pengaruh signifikan terhadap manajemen laba. Li dan Hung (2013) menjelaskan bahwa manajerial yang terlalu percaya diri pada perusahaan keluarga termotivasi melakukan manajemen laba karena pertimbangan adanya kompensasi yang diterima dan mengarah pada pengaruh entrenchment. Selain itu, penelitian ini mendukung teori keagenan pada konflik keagenan tipe II yang menjelaskan bahwa pihak manajemen yang masih memiliki hubungan keluarga dengan pemegang saham mayoritas cenderung mementingkan pemenuhan saham mayoritas dibandingkan dengan pemegang saham minoritas dan dapat melakukan intervensi untuk memanipulasi laba untuk memaksimalkan keuntungan (Chi et al., 2015; Wang, 2006).

\section{KESIMPULAN DAN SARAN}

\section{Kesimpulan}

Berdasarkan hasil penelitian yang dilakukan, maka dapat ditarik kesimpulan managerial overconfidence berhubungan positif dan signifikan terhadap manajemen laba. Artinya, adanya manajerial yang terlalu percaya diri (managerial overconfidence) dalam suatu perusahaan akan melaporkan laba yang tinggi dan melakukan manajemen laba yang lebih besar. Selain itu, kepemilikan keluarga dianggap tidak mampu mempengaruhi (memperlemah) hubungan antara managerial overconfidence terhadap manajemen laba. Adanya keterlibatan keluarga dalam suatu perusahaan belum tentu dapat memperlemah sikap manajerial yang terlalu percaya diri dalam melakukan manajemen laba.

\section{Saran}

Berdasarkan hasil penelitian, maka saran yang dapat diberikan sebagai berikut.

1. Perusahaan dapat mempertimbangkan dalam memilih CEO dan para manajer. Apabila perusahaan melakukan rekrutmen pada manajerial yang memiliki sifat terlalu percaya diri (perilaku oportunistik atau bahkan tidak rasional) maka akan mengganggu nilai perusahaan.

2. Perusahaan sebaiknya membuat pengawasan internal yang dapat digunakan untuk memantau perilaku oportunistik yang dimiliki para manajerial perusahaan

3. Penelitian ini hanya menggunakan perusahaan dalam industri manufaktur saja sebagai sampel sehingga tidak dapat digeneralisasikan pada industri lain selain industri manufaktur. Penelitian selanjutnya dapat memperluas sampel penelitian ke sektor industri lainnya, misalnya industri properti dan real estate.

\section{DAFTAR PUSTAKA}

Abdullah, S. N. dan K. N. I. K. Ismail. 2016. Woman Directors, Family Ownership, and Earnings Management in Malaysia. Asian Review of Accounting. Vol. 24 (4):525-550.

Ali, A., T. Chen, dan S. Radhakrishnan. 2007. Corporate Disclosures by Family Firms. Journal of Accounting and Economics. Vol. 44 (1-2): 238-286. 
Anderson, R. C. dan D. M. Reeb. 2003. American Finance Association FoundingFamily Ownership and Firm Performance: Evidence from the S dan P 500. The Journal of Finance. Vol.58 (3): 1301-1328.

Atmaja, L. S., J. Haman, dan G. Tanewski. 2011. The Role of Board Independence in Mitigating Agency Problem II in Australian Family Firms. British Accounting Review. Vol.43 (3): 230-246.

Ball, R. dan L. Shivakumar. 2005. Earnings Quality in UK Private Firms: Comparative Loss Recognition Timeliness. Journal of Accounting and Economics. Vol. 39 (1): 83-128.

Bhandari, G. dan R. Deaves. 2006. The Demographics of Overconfidence. The Journal of Behavioral Finance. Vol. 7 (1): 5-11.

Chen, S., K. Ho, dan P. Ho. 2014. CEO overconfidence and Long-Term Performance Following R\&D Increases. Financial Management. Vol. 43 (2): 245-269.

Chi, C. W, K. Hung, H. W. Cheng, danP. T. Lieu. 2015. Family Firms and Earnings Management in Taiwan: Influence Of Corporate Governance. International Review of Economics and Finance. Vol.36: 88-98.

Chu, W. 2011. Family ownership and firm performance: Influence of Family Management, Family Control, and Firm Size. Asia Pasific Journal of Management. Vol.28 (4): 833- 851.

Eddleston, K. danF. W. Kellermanns. 2007. Destructive and Productive Family Relationship: A Stewardship Theory Perspective. Journal of Business Venturing. Vol. 22 (4): 545-565.

Fields, T. D., T. Z. Lys, dan L. Vincent. 2001. Empirical Research on Accounting Choice.

Journal of Accounting and Economics. Vol. 31 (1-3): 255-307.

Francis, J., R. Lafond,P. Olsson, dan K. Schipper. 2005. The Market Pricing of Accruals Quality. Journal of Accounting and Economics. Vol.39 (2): 295-327.

Fung, S. Y., L. N. Su, dan R. J. Gul. 2013. Investor Legal Protection and Earnings Management: A study of Chinese H-shares and Hong Kong Shares. Journal of Accounting and Public Policy. Vol.32 (5): 392-409.

Ghozali, I. 2018. Aplikasi Analisis Multivariate dengan Program IBM SPSS 25. Semarang: Badan Penerbit Universitas Diponegoro.

Healy, P.M. dan J. W. Wahlen. 1999. A Review Of The Earnings Management Literature And Its Implications For Standard Setting. Accounting Horizons. Vol. 13 (4): 365-383.

Hillary, G. dan C. Hsu. 2011. Endogenous Overconfidence in Managerial Forecasts. Journal of Accounting and Economics. Vol. 51 (3): 300-313.

Hribar, P., dan H. Yang. 2016. CEO Overconfidence and Management Forecasting. Contemporary Accounting Research. Vol. 33 (1): 204-227.

Hsieh, T., J. C. Bedard, dan K. M. Johnstone. 2014. CEO overconfidence and Earnings Management During Shifting Regulatory Regimes. Journal of Business Finance and Accounting. Vol. 41 (9): 1243-1268.

Jaggi, B., S. Leung, dan F. Gul. 2009. Family Control, Board Independence and Earnings Management: Evidence Based on Hong Kong Firms. Journal of Accounting and Public Policy. Vol. 28 (4): 281-300.

Jensen, M. C. danW. H. Meckling. 1976. Theory of The Firm: Managerial Behavior, Agency Costs and Ownership Structure. Journal of Financial Economics. Vol.3 (4): 305-360. 
La Porta, R., F. Lopez-de-Sllanes, A. Shleifer, dan R. W. Vishny. 1998. Law and Finance. Journal of Political Economy. Vol. 106 (6): 11131-55.

Leung, S., G. Richardson, dan B. Jaggi. 2014. Corporate Board and Board Committee Independence, Firm Performance, and Family Ownership Concentration: An Analysis Based on Hong Kong Firms. Journal of Contemporary Accounting and Economics. Vol.10 (1): 16-31.

Libby, R. dan K. Rennekamp. 2012. Self-Serving Atbribution Bias, Overconfidence, and the Issuance of Management Forecasts. Journal of Accounting Research. Vol. 50 (1): 197-231.

Lin, Y. H., S. Y. Hu, dan M. S. Chen. 2005. Managerial Optimism and Corporate Investment: Some Empirical Evidence from Taiwan. Pacific-Basin Finance Journal. Vol.13 (5): 523-546.

Li, I-C. dan J-H. Hung. 2013. The Moderating Effects of Family Control on The Relation between Managerial overconfidence and Earnings Management. Review of Pacific Basin Financial Markets and Policies. Vol.16(2): 1-33.

Miller, D.,I. L. Breton-Miller, dan B. Scholnick. 2008. Stewardship vs. Stagnation: An Empirical Comparasion of Small Family and Nonfamily Businesses. Journal of Management Studies. Vol.45(1): 51-78.

Nordin, W., dan W. Hussin. 2009. The Impact of Family-firm Structure and Board Composition on Corporate Transparency: Evidence Based on Segment Disclosures in Malaysia. International Journal of Accounting. Vol. 44 (4): 313333.

Presley, T.J., dan L. J. Abbott. 2013. CEO Overconfidence and the Incidence of Financial Restatement. Advances in Accounting, Incorporating Advances in International Accounting. Vol. 29 (1): 74-84.

Roychowdhury, S. 2006. Earnings Management Through Real Activities Manipulation. Journal of Accounting and Economics. Vol. 42 (3): 335-370.

Schrand, C. M. danS. L. C. Zechman. 2012. Executive Overconfidence and The Slippery Slope to Financial Misreporting. Journal of Accounting and Economics. Vol.53 (1- 2):311-329.

Srinidhi, B. N., S. He, dan M. Firth. 2014. The Effect of Governance on Specialist Auditor Choice and Audit Fees in U.S. Family Firms. The Accounting Review. Vol.89 (6): 2297- 2329.

Subramanyam, K. R. 2014. Financial Statement Analysis, Eleventh Edition. United States of America: McGraw-Hill Education.

Wang, D. 2006. Founding Family Ownership and Earnings Quality. Journal of Accounting Research. Vol.44 (3): 619-656.

Wolk, H. I., J. L. Dodd, dan J. J. 2013. Accounting Theory Conceptual Issues in a Political and Economic Enviroment. United States of America: SAGE.

Yuan, J. dan Y. Jiang. 2008. Accounting Information Quality, Free Cash Flow and Overinvestment: A Chinese Study. The Business Review, Cambridge. Vol. 11(1): 159- 166. 